Journal of Mathematics and Informatics

Vol. 16, 2019, 127-137

ISSN: 2349-0632 (P), 2349-0640 (online)

Published 12 May 2019

www.researchmathsci.org

DOI: http://dx.doi.org/10.22457/jmi.143av16a12

Journal of

Mathematics and

Informatics

\title{
Impacts of Return Process Service Quality on Customers' Purchase Intention through e-Commerce Website in Bangladesh
}

\author{
Nazir Uddin Mohammad \\ School of Economics and Management \\ Chongqing University of Posts and Telecommunications \\ Chongqing-400065 China. Email: nazir b.pharm@yahoo.com
}

Received 20 April 2019; accepted 3 May 2019

\begin{abstract}
Return process service quality is one of the after-sales services provided by retailers. This return service quality enables customers who are not satisfied with their purchased items to receive money back within the return period of time. Based on the researching achievements of predecessors we designed research concept model that demonstrates five independent variables: money back guaranty, return cost, return duration, return place and return restrictions and one dependent variable: customer purchase intention. Self-administered questionnaires were used and 423 responses were collected in Bangladesh to test the model. Multiple linear regression is used to calculate the statistic result while reliability analysis was conducted; to check the validity KMO and Bartlett's test was applied and correlation is also used to analyze the relationship between the variables. Moreover, return process service quality has a significant positive impact on customer purchase intention; in this way, we found that a $1 \%$ change in return duration (RD) leads to $30.8 \%$ increase in customer purchase intention (CPI). This result suggests that return duration is the major dimension in influencing customer purchase intention. In addition, The result shows that return process service quality increases customer purchase intention by adjusting return duration, doing affordable return cost, availability of return place, reasonable return restrictions and providing money back guaranty. According to the findings of the study, not only Bangladeshi e-commerce enterprises but also low developed countries' enterprises should focus more on the product return service quality so as to improve customer purchase intention in ecommerce.
\end{abstract}

Keywords: Return process service quality, customer purchase intention, dimensions of return process service quality

AMS Mathematics Subject Classification (2010): 91G50

\section{Introduction}

The increased number of internet users and the growing popularity of online shopping are showing the great prospect of e-commerce development in Bangladesh. The application of e-commerce will be different in Bangladesh than it is in China, Europe and America 


\section{Nazir Uddin Mohammad}

because of the social and cultural difference. Bangladesh has ninety-one million internet users, about 13.7 percent of the total population. Products purchased over the Internet are often can be paid through online or offline. Credit and debit cards are the most popular payment method worldwide in terms of the online transaction purchase value. In Bangladesh, consumers are still reluctant to use the electronic mode of payment or online payment system. A survey report regarding online marketplace in Bangladesh published in 2015; their research shows that "Cash-on-delivery is the most commonly used payment method in Bangladesh, accounting for $\mathbf{9 5}$ percent of e-commerce transactions. On the other hand, only $1 \%$ used credit cards, $2 \%$ used Bkash or other mobile transactions and $2 \%$ used banking channels. The higher number of cash on delivery means people do not have optimal faith in the e-commerce company provided service, especially in return service. Return process service quality is defined as customer evaluation of the quality of online service delivery provided by the e-commerce website and business. The traditional return problem can be classified into two categories: one is the return problem between the retailer and the supplier, and the other one is the return problem between the retailer and the consumer. In the e-commerce shopping environment, the return problem between retailers and consumers is more obvious. Especially in Bangladesh, though there is a nominal return process offered by ecommerce in real. After a customer experienced dissatisfied product then some ecommerce retailers allow returning and some retailers directly neglect about the return. Based on the researching achievements of predecessors, return process service quality can be divided into five dimensions: money back guaranty, return cost, return duration, return place and return restrictions. The main purpose of this study is to examine the relationship between dimensions of return process service quality and customer purchase intention of Bangladeshi e-commerce and points out that return process service quality can enhance customer purchase intention. Based on the general management, return process service quality can reduce customer perceived effort level, return operation is more convenient and customers are more humble to return behavior. In a Bangladeshi ecommerce website, due to the poor returning service quality, customer purchase intention is lower than the physical store. In the network environment, consumers can only recognize goods by the merchant's graphic description, but may not directly distinguish the quality and performance. At the same time, the authenticity of the information and the return service will be provided by the business cannot be guaranteed, making the uncertainty of network customers to increase, and these will enhance customer's perceived risk. Poel and Leunis confirm that the return process service quality can reduce consumer perceived economic and product risk in the shopping process. If consumers are not satisfied with the product, consumers can easily return through the return policy, to some extent return process service quality can reduce customer concerns before shopping.

\section{Literature review}

\subsection{E-commerce in Bangladesh}

In 2016 the number of internet users across more than three billion users around the world. Internet is flourishing dramatically as a powerful and popular way of communication. Bangladesh e-commerce is still in developing phase, though it has started in the late 1990s (e-cab, 2016). After struggling a long period of time the situation 
Impacts of Return Process Service Quality on Customers' Purchase Intention through eCommerce Website in Bangladesh

has started changing in 2012-2013; when two e-commerce website akhoni and ajkerdeal present themselves to the online consumers. It has received good appreciation from the consumers mainly in the capital city Dhaka. The outcome of the E-commerce venture not only enticed business entrepreneur to invest and hit the market from Bangladesh but also from abroad as well. Some foreign investor like Olx, daraz, and kaymu joined the competition along with local. There has been decent growth in e-commerce in the last couple of years; There are more than $\mathbf{2 5 0 0}$ e-commerce websites and around $\mathbf{8 , 0 0 0}$ ecommerce pages on Facebook that operating business (export.gov, 2017) [4]. In November 2017, a report published and mentioned that the e-commerce sector expected to grow 70\% and the market size is estimated $\$ 110-115$ million compared to 2016, which was $\$ 65-70$ million. Though e-commerce only contributes $0.7 \%$ of the country's total retail market (new age bd, 2017). The market is growing fast, and the sales volume is surging. The very recent report shows that the current e-commerce market size increased to $\$ 230-240$ million and annual growth is $45-50 \%$ [4].

Customer purchase intention has been used frequently to identify buying likelihoods for products within defined time periods [5]. Return process service quality has been considered as an important antecedent to behavioral intentions. For example, Bitner found that perceived return service quality influences behavioral intentions in terms of word-of-mouth and repurchase intention [6]. A high level of return service quality was associated with frequent patronage in the restaurant industry. In the research of the website and online stores, (Kuo 2003) pointed out that the return service quality of the online community is positively related to continuous use, referral, and loyalty.

\section{Concept model and hypothesis development}

Availability of a service guarantee is an important dimension that can be leveraged in offensive and defensive marketing initiatives. Three different categories of warranties are identified in the literature: extended warranty, extended maintenance contract, and money back guarantee. A money back guaranty has been shown to be an emergent risk reduction strategy for consumers before purchasing the commodity. Therefore consumers' feel secure to shop online if they are sure that they will get their money back in case of discrepancy with the item they have purchased [10].

H1: In return process service quality money back guaranty has a positive impact on customer purchase intention.

The return cost is reflected in two aspects: Refund of commodity and the expenses of return. Chu and Gerstner analysis three refund policies: no questions asked, no refunds, and verifiable problems only, and show that 'no questions asked' as the most efficient way to handle consumer opportunism The expenses of return has also three policies: Return cost stands for the value of the products, the cost stands for the volume of the products and the cost stands for the distance of the return warehouse.

H2: In return process service quality Return cost has a positive impact on customer purchase intention.

According to the Value-Determination theory of marketing, the market price of the commodity has a certain time, so the 'return duration' is also a limiting factor in the return policy. As for the efforts, Davis [8] firstly postulates the concept of "Hassle". Enterprises can adjust the level of "Hassle", affecting consumers return behavior. Davis 
Nazir Uddin Mohammad

[8] believed that the amount of return duration, effort, and extra expense are part of the effort of return.

H3: In return process service quality Return duration has a positive impact on customer purchase intention

Availability of return place is an important dimension of return process service quality. Four different characteristics of return place are identified in the literature: availability of return place, location of return place, opening hours of return place and delivery personnel's attitude. Delivery personnel's attitude is an important risk reduction strategy for customers [10].

H4: In return process service quality Return place has a positive impact on customer purchase intention

In order to eliminate the concerns of consumers to promote the consumption of goods, some sellers offer "Return of goods without reasons" policy. Related legal regards "Return of goods without reasons" as the basic right of consumers, in order to alleviate the unfair information in the online shopping environment between the merchants and consumers. With the proposition of this policy, many problems are alleviated to used.

H5: In return process service quality Return restrictions has a positive impact on customer purchase intention.

\begin{tabular}{|l|l|}
\hline Money back guaranty & $\mathrm{H1}$ \\
\hline Return cost & $\mathrm{H} 2$ \\
\hline Return duration & $\mathrm{H3}$ \\
\hline Return place & $\mathrm{H} 4$ \\
\hline Return restrictions & $\mathrm{H5}$ \\
\hline
\end{tabular}

Figure 1: Research concept model

\section{Research method}

\subsection{Sample and data collection}

To examine the relationship between the various dimensions of return process service quality and customer purchase intention we used customer survey as a medium to collect data. Forming of the questionnaire is to see the relationship between independent variables that can influence the dependent variable. In simple random sampling chooses samples from the population individually based on their convenient accessibility and proximity to the researcher. Given the large population of Bangladeshi Internet users, it is difficult to decide how large the sample size should be. In this study, only online survey distribution strategy was carried out. The author then posted the survey link on different Bangladeshi social media platforms as well as Chinese social media platform includes facebook, twitter, wechat and other applications such as instant messaging tools (WhatsApp). Sampling is taking a fraction of a population to represent the whole population but the researcher only managed to find $\mathbf{4 3 4}$ people to become respondents. I got properly answer $\mathbf{4 2 3}$ and work on it. 
Impacts of Return Process Service Quality on Customers' Purchase Intention through eCommerce Website in Bangladesh

\subsection{Measurement instruments}

In this study, all constructs are measured by multiple items in a five-point Likert-scale (1strongly disagree, 5 -strongly agree). Return process service quality (RSQ) comprises five dimensions: money back guaranty, return cost, return duration, return place and return restrictions. Each dimension was measured with four items adapted from existing literature and experts' opinion.

Table 1: Variable measurement scales

\begin{tabular}{|c|c|c|}
\hline Variables & Measurement & Reference \\
\hline $\begin{array}{l}\text { Customer } \\
\text { purchase } \\
\text { intention }\end{array}$ & $\begin{array}{l}\text { Generally, online shopping is a pleasant experience } \\
\text { I like online shopping } \\
\text { I feel online shopping is satisfying to me } \\
\text { Online shopping is attracting to me } \\
\text { If the return process is up to expectation, I am planning to } \\
\text { buy } \\
\text { online through e-commerce website in future }\end{array}$ & $\begin{array}{l}\text { N.Z.Hosein } \\
\text { Z.Pei, } \\
\text { A.Paswan, } \\
\text { R.Yan } 2014\end{array}$ \\
\hline $\begin{array}{l}\text { Money } \\
\text { back } \\
\text { guaranty }\end{array}$ & $\begin{array}{l}\text { The E-commerce retailer provides me with convenient } \\
\text { options for returning items } \\
\text { The E-commerce retailer offers a meaningful guarantee on } \\
\text { returns product } \\
\text { The E-commerce retailer takes care of problems promptly } \\
\text { in the reverse flow } \\
\text { If I return the products the seller can refund me all the } \\
\text { money }\end{array}$ & $\begin{array}{l}\text { S. Davios, } \\
\text { T.T.Kidane } \\
2016\end{array}$ \\
\hline Return cost & $\begin{array}{l}\text { The return cost is totally affordable for me. } \\
\text { Return cost stands for the value of the products } \\
\text { Return cost stands for the volume of the products } \\
\text { Return cost stands for the distance of the return warehouse }\end{array}$ & $\begin{array}{l}\text { M.Wang \& } \\
\text { H.J.Qu, } 2017 \\
\text { I.Russo and I. } \\
\text { Confente }\end{array}$ \\
\hline $\begin{array}{l}\text { Return } \\
\text { duration }\end{array}$ & $\begin{array}{l}\text { The returning time duration is acceptable for me until the } \\
\text { seller receive the products } \\
\text { Fragile products usually take one more days } \\
\text { Return duration stands for the volume of the products } \\
\text { Return duration stands for the distance of the return } \\
\text { warehouse }\end{array}$ & $\begin{array}{l}\text { M.Wang \& } \\
\text { H.J.Qu } 2017\end{array}$ \\
\hline $\begin{array}{l}\text { Return } \\
\text { place }\end{array}$ & $\begin{array}{l}\text { The availability of return place for returning product is } \\
\text { satisfying me } \\
\text { The location of return place is satisfying me } \\
\text { The opening hours of returning place are satisfying me } \\
\text { Delivery personnel's attitude is satisfying me }\end{array}$ & $\begin{array}{l}\text { N.K.Jain, } \\
\text { I.Russo and } \\
\text { I.Confente }\end{array}$ \\
\hline
\end{tabular}


Nazir Uddin Mohammad

\begin{tabular}{|l|l|l|}
\hline $\begin{array}{l}\text { Return } \\
\text { restrictions }\end{array}$ & $\begin{array}{l}\text { There are not unreasonable return restrictions when I } \\
\text { return the goods }\end{array}$ & $\begin{array}{l}\text { M.Wang \& } \\
\text { More than 2017 days used received products have return }\end{array}$ \\
& $\begin{array}{l}\text { restrictions } \\
\text { Low-value products less than 50 taka are not permitted to } \\
\text { return } \\
\text { Damaged products do not allow returning }\end{array}$ & \\
\hline
\end{tabular}

\section{Data analysis and result}

The reliability of constructs was measured using internal consistency coefficient alpha and from the theory of Cronbach's alpha; the value in all cases is appreciably higher than the recommended value of 0.7 . All the constructs were found to possess excellent reliability. The table shows the scores of constructs reliability are ranging from 0.781 to 0.836 ; the highest reliability of the constructs was 0.836 (Return restriction) and the lowest reliability was 0.781 (Return place). Therefore, all constructs are valid for analysis (see Table 2).

Table 2: Reliability result of each variable

\begin{tabular}{lcc}
\hline Constructs & Cronbach's alpha & No. of items \\
\hline Money back guaranty & 0.802 & 4 \\
Return cost & 0.800 & 4 \\
Return duration & 0.791 & 4 \\
Return place & 0.781 & 4 \\
Return restriction & 0.836 & 5 \\
Customer purchase intention & 0.804 & \\
\hline
\end{tabular}

Table 3 demonstrates the appropriateness of factor analysis Kaiser-Meyer-Olkin (KMO) and Bartlett's test Statistic. If, the KMO value is greater than 0.6 is considered as adequate (Kaiser and Rice, 1974). From this table, we found that the value of KaiserMeyer-Olkin Measure of Sampling Adequacy is .961 that is greater than 0.6 indicates the value of Kaiser-Meyer is acceptable and the value of Bartlett's test of Sphericity is also statistically significant and acceptable.

Table 3: Validity result

\begin{tabular}{|c|l}
\hline Kaiser-Meyer-Olkin measure of Sampling Adequacy. & .961 \\
Bartlett's Test of Sphericity Approx. Chi-square & $6.396 \mathrm{E} 3$ \\
df & 300 \\
Sig. & .000
\end{tabular}


Impacts of Return Process Service Quality on Customers' Purchase Intention through e-

Commerce Website in Bangladesh

Table 4: Correlation Result

\begin{tabular}{|c|c|c|c|c|c|c|}
\hline & MBG & $\mathrm{RC}$ & RD & $\mathrm{RP}$ & $\mathrm{RR}$ & CPI \\
\hline MBG & 1 & & & & & \\
\hline $\mathrm{RC}$ & $.738^{* *}$ & 1 & & & & \\
\hline $\mathrm{RD}$ & $.721^{* *}$ & $.768^{* *}$ & 1 & & & \\
\hline $\mathrm{RP}$ & $.686^{* *}$ & $.740^{* *}$ & $.791^{* *}$ & 1 & & \\
\hline $\mathrm{RR}$ & $.707^{* *}$ & $.735^{* *}$ & $.755^{* *}$ & $.818^{* * *}$ & 1 & \\
\hline CPI & $.677^{* * *}$ & $.725^{* * *}$ & $.764^{* * *}$ & $.735^{* *}$ & $.742^{* * *}$ & 1 \\
\hline & MBG & $\mathrm{RC}$ & $\mathrm{RD}$ & $\mathrm{RP}$ & RR & CPI \\
\hline Mean & 3.6667 & 3.3994 & 3.3232 & 3.2470 & 3.2642 & 3.2565 \\
\hline Stand. & 1.2992 & 1.2335 & 1.2764 & 1.3079 & 1.2906 & 1.3076 \\
\hline
\end{tabular}

Table 4 indicates that the Pearson correlation matrices of the components in the study. Statistically significant correlation coefficients $(\mathrm{p}<0.01)$ were found between each pair of components. The highest correlation coefficient $(\mathrm{R}=0.818, \mathrm{p}<0.01)$ is between return place and return restriction which means there is a positive significant relationship between both variables. This is followed by the relationship between return duration and return place $(\mathrm{R}=0.791, \mathrm{p}<0.01)$ which means there is also a positive significant relationship between both variables. The findings demonstrate that the correlation between sub-constructs of RSQ and customer purchase intention are positive and significant as expected.

\subsection{Multiple regression analysis}

Multiple regression is an extension of simple linear regression. It is used when we want to predict the value of a variable based on the value of two or more other variables. Linear regression attempts to model the relationship between two variables by fitting a linear equation to observed data. One variable is considered to be an explanatory variable, and the other is considered to be a dependent variable. There are one dependent variable and five main determinants and three control variables. So there will be one regression model.

\section{$C P I=\alpha+\beta 1 M B G+\beta 2 R C+\beta 3 R D+\beta 4 R P+\beta 5 R R+\beta 6$ age $+\beta 7$ profession $+\beta 8$ income}

Table 5: Model summary and ANOVA result

\begin{tabular}{|l|l|l|l|l|l|l|}
\hline Model & $\mathrm{R}$ & R Square & $\begin{array}{l}\text { Adjusted R } \\
\text { Square }\end{array}$ & $\begin{array}{l}\text { Std. Error of the } \\
\text { Estimate }\end{array}$ & F \\
\hline 1 & $.831^{\mathrm{a}}$ & .690 & .684 & .54840 & 115.434 & $.000^{\mathrm{a}}$ \\
\hline
\end{tabular}

a. Predictors (constant) Profession, Age, Income, MBG, RC, RD, RP, RR

b. Dependent variable: CPI 


\section{Nazir Uddin Mohammad}

Here, CPI means customer purchase intention, MBG means money back guaranty, $\mathrm{RC}$ means return cost, $\mathrm{RD}$ means return duration, $\mathrm{RP}$ means return place, $\mathrm{RR}$ means return restriction. Besides the analysis, we considered 3 control variables: age, profession, income.

The table showed that $\mathrm{R}$-value is 0.831 . This value indicates that there is a strong impact of these five independent variables on customer purchase intention. This means there is an associative relation exists between customer purchase intention and the selected independent variables. It can also be observed that the coefficient of determination i.e the $\mathrm{R}$-square $\left(\mathrm{R}^{2}\right)$ value is 0.690 which represents that $69 \%$ variation of the dependent variable (overall customer purchase intention) can be explained by the independent variables. This also indicates that the strength of the associative relationship between customer purchase intention and the selected five independent variables is good.

From this table, it has been founded that, the value of F-statistics is 115.434 and the level of significance is 0.000 . It indicates that the overall model was a reasonable fit and there was a statistically significant association between customer purchase intention and selected independent variables. It can be concluded that there is a strong associative relationship exists between customer purchase intention and selected independent variables.

Table 6: Coefficient Result

\begin{tabular}{|l|l|l|l|l|l|}
\hline & $\begin{array}{l}\text { Unstandardized } \\
\text { Coefficients }\end{array}$ & & & \multicolumn{2}{|l|}{ Collinearity Statistics } \\
\cline { 4 - 6 } Bodel & Balue & T value & Sig. & Tolerance & VIF \\
\hline MBG & .087 & 2.023 & .044 & .370 & 2.704 \\
\hline RC & .168 & 3.397 & .001 & .307 & 3.252 \\
\hline RD & .308 & 6.001 & .000 & .275 & 3.642 \\
\hline RP & .119 & 2.234 & .026 & .249 & 4.016 \\
\hline RR & .171 & 3.446 & .001 & .265 & 3.777 \\
\hline Age & -.068 & -2.083 & .038 & .893 & 1.120 \\
\hline Profession & -.126 & -3.840 & .000 & .867 & 1.154 \\
\hline Income & .023 & .978 & .329 & .934 & 1.071 \\
\hline
\end{tabular}

Firstly, the VIF shows the result of collinearity test. The collinearity is not significant if $0<\mathrm{VIF}<10$. The result demonstrates that there is no collinearity in this model. Secondly the result shows, unstandardized coefficients illustrate a partial change in the customer purchase intention due to one unit change in each of the independent variables; it has been found that MBG, RC, RD, RP, RR, Age, and Profession play significant positive roles on CPI; if we enter all the independent variables together. The table also indicates that return duration, return cost and return restriction is the most influential dimensions of return process service quality for customer purchase intention with biggest $\mathrm{B}$ value $=0.308$.

\subsection{Explanation of the result}

Coefficients analysis of the variables is influencing customer purchase intention. The result indicates that a $1 \%$ change in return duration (RD) leads to $30.8 \%$ increase in customer purchase intention (CPI). This result suggests that return duration is the major 
Impacts of Return Process Service Quality on Customers' Purchase Intention through eCommerce Website in Bangladesh

dimension in influencing customer purchase intention. There is a significant and positive relationship between return duration and customer purchase intention $(\mathrm{P}<0.01)$. This positive relationship indicates that the higher adjustable return duration in return process service quality is expected that the higher customer purchase intention in e-commerce website in Bangladesh. Similarly, the partial change in customer purchase intention of Bangladeshi e-commerce due to $1 \%$ change in return cost leads to $16.8 \%$ increase customer purchase intention. It means return cost (RC) also plays a significant positive role on customer purchase intention in Bangladeshi e-commerce. The positive relationship indicates that the higher affordable return cost in return process service quality is expected that the higher customer purchase intention in e-commerce website in Bangladesh. The partial change in customer purchase intention of Bangladeshi ecommerce due to $1 \%$ change in return place leads to $11.9 \%$ increase customer purchase intention. It means return place (RP) also plays a significant positive role on customer purchase intention in Bangladeshi e-commerce. This positive relationship indicates that the higher available return place in return process service quality is expected that the higher customer purchase intention in e-commerce website in Bangladesh. The partial change in customer purchase intention of Bangladeshi e-commerce due to $1 \%$ change in return restriction leads to $17.1 \%$ increase customer purchase intention. It means return restriction (RR) also plays a significant positive role on customer purchase intention in Bangladeshi e-commerce. This positive relationship indicates that the higher reasonable return restriction in return process service quality is expected that the higher customer purchase intention in e-commerce website in Bangladesh. The partial change in customer purchase intention of Bangladeshi e-commerce due to $1 \%$ change in money back guaranty leads to $8.7 \%$ increase customer purchase intention. It means money back guaranty (MBG) also plays a significant positive role on customer purchase intention in Bangladeshi e-commerce.

Table 7: Hypothesis Result

\begin{tabular}{|c|c|c|c|}
\hline Hypothesis & & Estimate & P value \\
\hline $\mathrm{H} 1$ & $\begin{array}{l}\text { return process service quality } \leftarrow \text { money } \\
\text { back guaranty }\end{array}$ & .087 & $\begin{array}{l}.044(\mathrm{P}<.05) \\
\text { Supported }\end{array}$ \\
\hline $\mathrm{H} 2$ & $\begin{array}{l}\text { return process service quality } \leftarrow \text { return } \\
\text { cost }\end{array}$ & .168 & $\begin{array}{l}.001(\mathrm{P}<.05) \\
\text { Supported }\end{array}$ \\
\hline $\mathrm{H} 3$ & $\begin{array}{l}\text { return process service quality } \longleftarrow \text { return } \\
\text { duration }\end{array}$ & .308 & $\begin{array}{l}.000(\mathrm{P}<.05) \\
\text { Supported }\end{array}$ \\
\hline $\mathrm{H} 4$ & $\begin{array}{l}\text { return process service quality } \longleftarrow \text { return } \\
\text { place }\end{array}$ & .119 & $\begin{array}{l}.026(\mathrm{P}<.05) \\
\text { Supported }\end{array}$ \\
\hline H5 & $\begin{array}{l}\text { return process service quality } \longleftarrow \text { return } \\
\text { restriction }\end{array}$ & .171 & $\begin{array}{l}.001(\mathrm{P}<.05) \\
\text { Supported }\end{array}$ \\
\hline
\end{tabular}

Thus, we can see $\mathrm{H} 1, \mathrm{H} 2, \mathrm{H} 3, \mathrm{H} 4$, and $\mathrm{H} 5$ are supported by empirical data.

\section{Conclusion and recommendations}

This study successfully identified the most influential dimensions of return process service quality those have an impact on customer purchase intention. The scales developed for money back guaranty, return cost, return duration, return place, and return restriction and customer purchase intention was tested using a diversified data set 


\section{Nazir Uddin Mohammad}

collected by a questionnaire survey among Bangladeshi e-commerce customers. The results demonstrate that money back guaranty, return cost, return duration, return place and return restrictions have a direct positive influence on customer purchase intention. Also, it has been revealed that there exists a strong positive relationship between customer purchase intention and selected five independent variables. Usually product return service quality is the important predictor of customer purchase intention but this study establishes all dimensions of return process service quality have a great impact on customer purchase intention. Every independent variable has good explanatory power for customer purchase intention. Although the researchers have been worked hard, there exists some limitation for this study. Such as- only five dimensions have been chosen as the independent variables and this research does not assures that these five dimensions of return process service quality are the only determinants of customer purchase intention of e-commerce in Bangladesh. Another workable limitation of this study is to represent data. Taking into consideration that the Bangladeshi e-commerce market is very large both geographically and demographically, it is difficult to have very diverse and large samples that fully represent the population. The sample size was not sufficient to conduct such kind of research. Due to inadequate publications on return service quality of Bangladeshi e-commerce; there was a lack of secondary data and the literature review part of this paper is not so much rich.

Based on the finding of the study we represent some recommendations; the above discussion indicates that customer purchase intention of e-commerce varies according to the nature of return service quality. So, it is the urgent need for the e-commerce service provider to take a necessary step to enhance the return service quality to make the customer an actual purchase. From the descriptive analysis, it has been founded that, most of the low-income customers were disagree about the return cost; therefore it is necessary to provide low-cost services to these kinds of customers. In this regard, the ecommerce retailer can provide free shipment for returning the dissatisfied products. It is also revealed that the young customers especially the students were disagreed regarding the return place and return restrictions. So, the service provider of the shipping company should make the service easy to use for these kinds of customers. In this purpose ecommerce company can arrange employee training and provide accurate guideline and also the e-commerce retailer can provide return products without any reason. This study also revealed that most of the mid-aged (31-40 years) customers have disagreed about the money back guaranty issue. So, the e-commerce company should take steps to make their mid aged customers happy. For example, they can introduce sending influential messages to ensure the guaranty and their good services to targeted customers. In this study, we give the practitioners more motivation to find new ways to improve the return services provided to the customers. We also collaborate with the 3rd parties to provide better return service to the customers. Hence the current research can be a reference for further research in the future, especially those researches related to return service quality, customer purchase intention, customer loyalty and customer satisfaction to switch.

\section{REFERENCES}

1. Y.-F.Kuo, C.-M.Wu and W.-J.Deng, The relationships among service quality, perceived value, customer satisfaction, and post-purchase intention in mobile valueadded services, Computers in Human Behavior, 25(4) (2009) 887-896. 
Impacts of Return Process Service Quality on Customers' Purchase Intention through eCommerce Website in Bangladesh

2. Md T.Karim and X.Qi, E-commerce development in Bangladesh, International Business Research, 11 (2018) 201-211.

3. M.Wang and H.J.Qu, Review of the research on the impact of online shopping return policy on consumer behavior, Journal of Business Administration Research, 6(2) (2017) $15-21$.

4. Md.Mohiuddin, Overview the E-commerce in Bangladesh, Journal of Business and Management, 16 (2014) 1-6.

5. S.P.Jeng, Increasing customer purchase intention through product return policies: The pivotal impacts of retailer brand familiarity and product categories, Journal of Retailing and Consumer Services, 39 (2017) 182-189.

6. S.M.Razavi, Relationships among service quality, customer satisfaction and customer perceived value: evidence from Iran's software industry, Journal of Management and Strategy, 3(3) (2012) 28-37.

7. I.Russo and I.Confente, The combined effect of product returns experience and switching costs on B2B customer re-purchase intent, Journal of Business \& Industrial Marketing, 31 (2017) 172-184.

8. S.Davis, Money back guaranty in retailing: matching products to consumer tastes, Journal of Retailing, 71(1) (1995) 7-22.

9. N.K.Jain, A conceptual framework for measuring e-fulfillment dimensions: a consumer perspective, Journal of Internet Commerce, 14 (2015) 363-383.

10. T.T.Kidane, Factors affecting consumers purchasing decision through E-commerce, International Conference on Industrial Engineering and Operations Management, Kuala Lumpur, Malaysia, March 8-10, 2016

11. S.F.Oishe, Customers' behavior towards e-commerce in Bangladesh: An empirical study on some selected B2C e-commerce sites, 32nd International Academic Conference, Geneva, 27 June 2017.

12. M.R.Hoque, M.A.Ali and M.A.Mahfuz, An Empirical Investigation on the Adoption of E-Commerce in Bangladesh, Asia Pacific Journal of Information Systems, 25(1) (2015) $1-24$.

13. Z.Pei, A.Paswan and R.Yan, E-tailer's return policy, consumer's perception of return policy fair and purchase intention, Journal of Retailing and Consumer Services, 21 (2014) 249 - 257. 